\title{
A Pré-Química na Escola de Rafael Sanzio
}

\author{
Raquel Gonçalves Maia* \\ Departamento de Química e Bioquímica, Faculdade de Ciências da Universidade de Lisboa \\ rmcgonc@gmail.com
}

\begin{abstract}
Estamos no Palácio do Vaticano, na mais soberba das “salas” de Rafael Sanzio. Em todo o seu esplendor, descendo a vertical da Filosofia, o fresco “A Escola de Atenas” deslumbra-nos com os seus filósofos e cientistas da Antiguidade Clássica e mesmo, porventura, dos Períodos Medieval e Renascentista. Quem é quem, nesta composição grandiosa (7,7 m de comprimento por 5,5 m de altura), de cenário imponente e cromaticamente soberba? Será que, para além daqueles que Rafael cuidadosamente identificou - colocando o célebre livro Timeu nas mãos de... Platão e o não menos célebre Ética nas mãos de... Aristóteles - cada corpo é indiferente a uma denominação? A nosso ver, Rafael representou, em "sala" aberta, uma comunidade composta por grandes pensadores, essencialmente filósofos e cientistas de diferentes épocas, desde o século VII a.C. até ao século XVI d.C.. A Pré-Química lá está representada, através de figuras eminentes da Escola Jónica, da Escola da Pluralidade e do Liceu. Os “elementos primordiais”, os “átomos” e as suas ligações de amor e ódio são o encantamento da História da Química.
\end{abstract}

\section{INTRODUÇÃO}

Nascera há pouco o século XVI quando a história da humanidade juntou um papa guerreiro e um jovem e talentoso pintor. Foi em Roma, mais propriamente no Vaticano, corria o inverno de 1508, que o Papa Júlio II se viu face a face com Rafael de Urbino. Este encontro, marcado pelo desejo de reflexo do poder papal pela via da Arte, foi determinante para a ascensão do moço pintor. Em consequência, nasceu um dos maiores expoentes da Renascença italiana, o fresco por todos denominado "A Escola de Atenas".

O Papa Júlio II, Giuliano della Rovere de seu nome, homem poderoso, em muito devia a sua fulgurante carreira eclesiástica à influência do tio, o Papa Sixto IV (Francesco della Rovere). A história recorda-o predominantemente pelas actuações políticas e bélicas que desenvolveu. Todavia, Júlio II bem merece ser recordado como patrono das Artes. Durante a década que durou o seu pontificado iniciou-se a construção da nova Basílica de São Pedro (1508).

O projecto fora encomendado ao arquitecto Donato Bramante, natural dos arredores de Urbino. Miguel Ângelo, considerado o maior artista vivo no seu tempo, pinta o tecto da Capela Sistina entre 1508 e 1512 . O jovem Rafael (Raffaello) Sanzio, convidado por Júlio II por sugestão do Duque de Urbino, seu sobrinho, e o apoio de Bramante, pinta os frescos das famosas Stanze di Raffaelo: Stanza della Segnatura (Figuras 1 e 2), Sala di Costantino, Stanza di Eliodoro e Stanza dell'Incendio del Borgo, a partir de 1509.

Nesta obra, o Sumo Pontífice pretende incorporar, e mesmo interligar, a filosofia pagã da Antiguidade Clássica e a

* Professora Catedrática aposentada

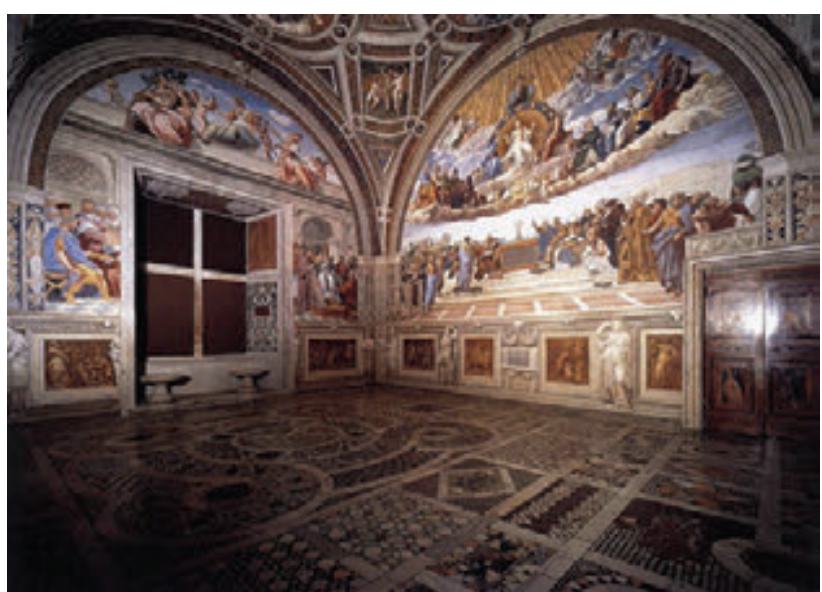

Figura 1 - Stanza della Segnatura (1), “Jurisprudência” e “A Discussão do Sacramento Divino”, Museu do Vaticano

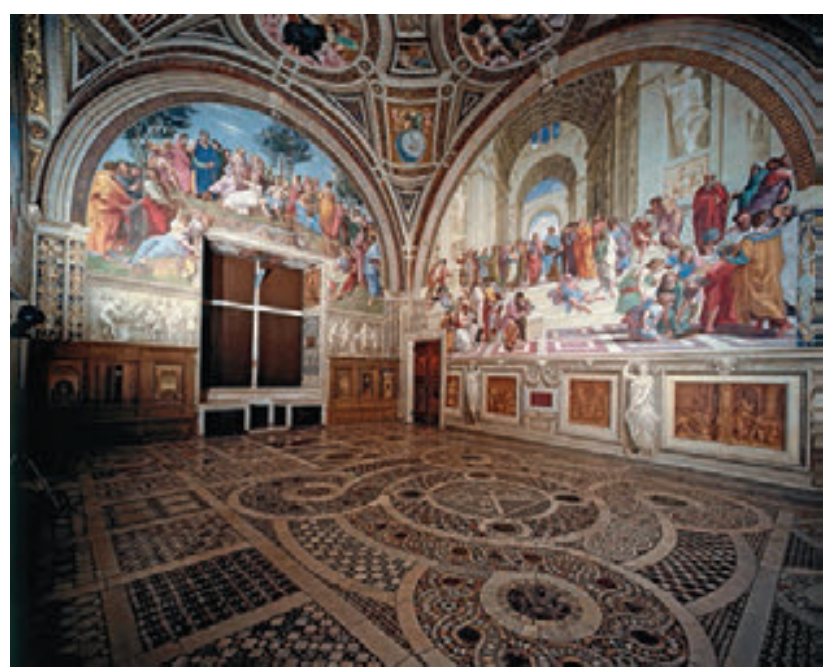

Figura 2 - Stanza della Segnatura (2), "Parnassus” e “A Escola de Atenas”, Museu do Vaticano

tradição cristã, a obra de Deus e as obras do Homem; sem contradição, nem conflito [1-6]. 


\section{2. "A Escola de Atenas"}

Júlio II gostou de Rafael Sanzio. Tudo jogava a favor do pintor: era "discreto, gentil e jovem” [7], tinha devoção e estima ancestral pela família do Papa e, ao contrário do que acontecia com o indomável Miguel Ângelo, era “moldável” aos desejos do Papa; e, evidentemente, tinha muito talento, talento aposto a uma graciosidade inexcedível. Primeiro uma parede e depois muitas de vários compartimentos aguardavam agora a mestria dos pincéis de Rafael.

O segundo fresco que Rafael Sanzio realizou foi “A Escola de Atenas", na longa parede em face de “A Disputa” [8]. O conhecimento adquirido e racionalizado pelos homens não devia ser encarado como oposto à doutrina cristã. Este era o pensamento de Júlio II que Rafael deveria artisticamente concretizar. Paralelas que se encontram no infinito...

O cenário arquitectónico de “A Escola de Atenas” é constituído essencialmente por uma sequência de arcos de pedra que delimitam o espaço, sem nunca o submergir. As aberturas que permitem vislumbrar o céu são essenciais para a respiração do fresco; uma tranquilidade luminosa, mas não solene, invade toda a cena. O cenário dir-se-ia grandioso e, no entanto, os arcos elevam-se pouco mais do que quatro vezes a altura das figuras. A imponência do conjunto é integralmente obra de sedução de Rafael.

A Filosofia/Ciência traduzida por “A Escola de Atenas” é a legitimação do conhecimento humano natural (da Natureza) pela igreja católica da época - como um canal de revelação do sobrenatural.

É preciso entender que, no Período da Alta Renascença, a Filosofia detinha um domínio que na sua generalidade, altamente abstrata e teórica, estudava o "ser enquanto ser”. De forma singularizada, contudo, a Filosofia preocupava-se com fenómenos ligados à observação, à experimentação e às técnicas, o que posteriormente veio a transferir-se para o domínio das Ciências; a queda dos graves, a classificação dos seres vivos, a identificação dos “elementos primordiais” e suas transformações ou a divisibilidade da matéria são disso exemplo. Muitos dos filósofos da Antiguidade Clássica e do Período Medieval são os cientistas da Antiguidade Clássica e do Período Medieval [9,10]. As distinções só começaram verdadeiramente a surgir no Período Renascentista, quantas vezes de forma incompreendida e mesmo violenta.

O conhecimento científico e as metodologias para o atingir evoluíram e diversificaram-se através dos tempos. Mas não nos iludamos tentando menorizar as descobertas de Pitágoras, Anaximandro, Heráclito, Aristóteles, Euclides ou Ptolomeu. Eles foram gigantes tanto na Filosofia quanto na Ciência, gigantes sobre os quais novos gigantes vieram a nascer. A História da Ciência e a História da Filosofia encontram-se em tempo finito.

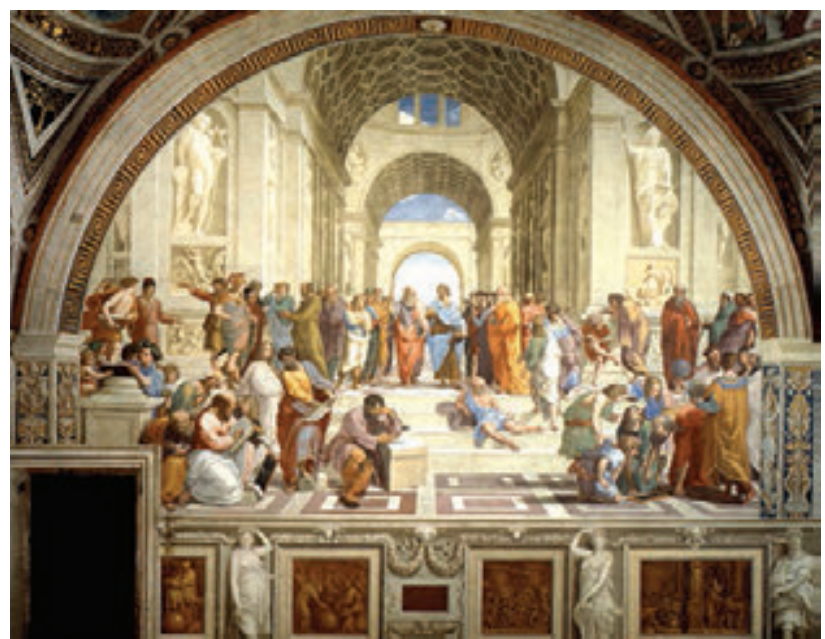

Figura 3 - “A Escola de Atenas” (1510/11), por Rafael Sanzio

\section{Filósofos e Cientistas}

Onde começa a História da Filosofia? Onde começa a História da Ciência? Os pré-socráticos da Escola Jónica, como Tales e Anaximandro de Mileto e, mesmo, Heráclito de Éfeso, da Escola Pitagórica (ou Itálica), como Pitágoras de Samos e Filolau de Crotona, da Escola Eleática, como Parménides e Zenão de Eleia, da Escola da Pluralidade, como Empédocles de Agrigento, Anaxágoras de Clazómenas e Leucipo e Demócrito de Abdera, e da Escola Eclética, como Diógenes de Apolónia e Arquelau de Atenas, pertencem à zona de transição do mito para o pensamento racional.

Certas exigências lendárias são forçosamente integradas numa nova lógica. O discurso, porém, é cada vez mais disciplinado e o universo da acção dos deuses substituído pelo universo da acção do homem. As narrativas que se vão suceder procuram descrever os acontecimentos com rigor analítico e repudiar as especulações onde a magia invade os fenómenos naturais.

Os “mistérios” abandonam-se ao jogo das perguntas e respostas com direito à interpretação que a observação sugere. A Natureza, no seu sentido amplo, constitui-se objecto de interrogação privilegiado. O estudo do "universo físico" pressupõe o desenvolvimento de uma metodologia científica. As qualidades tanto fazem parte do discurso filosófico quanto do científico; as quantidades materializam a cientificidade.

Em “A Escola de Atenas” estamos perante uma cena de teatro duma narrativa em movimento, onde os "actores" debitam o texto da peça. Quase podemos adivinhar os diálogos entre as personagens ou atinar com os pensamentos que afectam os homens isolados. A "Escola” de Rafael não é, não pode ser, a “Academia” de Platão, uma vez que as 56 figuras humanas que coabitam o mesmo recinto pictórico tiveram vivência diversificada no tempo e no espaço. Mas a ideia subjacente à construção do fresco tem uma importância excepcional. O legado da Grécia e de Roma para a cultura ocidental, filosófica e científica, bem merecia uma homenagem desta dimensão. 
A "leitura" da magnífica obra de Rafael Sanzio é fascinante. Que importa que o século XIII espreite por sobre o ombro do século VI a.C., se aquele mais deseja aprender sobre a perfeição dos números melódicos? Nada de intrigante se uma acesa discussão, reveladora do Universo e da Terra, tenha lugar entre um mancebo do século VII a.C e outro do século II; e, para mais, atentamente escutada por pintores renascentistas...

E nem só de 56 “professores” e “alunos” vive a Escola: Platão veste a pele de Leonardo da Vinci, Euclides a de Bramante, Heráclito a de Miguel Ângelo. E mais são, sem dúvida, as duplicações.

A controvérsia é muita sobre a identificação da maior parte das figuras que neste fresco estudam, reflectem ou especulam sobre ideias, fenómenos e experiências de inegável relevância social. Salientaremos, porém, algumas convergências [1-3, 11,12].

Na parte central superior, Rafael colocou Platão (1) e o seu antigo discípulo Aristóteles (2). Na parte esquerda do fresco destacam-se pequenos agrupamentos. São socráticos, sofistas, órficos e pitagóricos. Sócrates (3) ilustra, pela expressão dos seus dedos, o silogismo, duas premissas e uma conclusão. Pitágoras (4) transcreve as relações numéricas que permitem os sons musicais. No nível inferior, mas em evidente destaque, surge Heráclito de Éfeso (5). É uma das figuras que não estava presente no esquema inicial de Rafael que se pode ver actualmente na Pinacoteca Ambrosiana.

Na parte direita de “A Escola de Atenas” encontramos um padrão semelhante de disposição dos intervenientes, ainda que sem ponta de repetição. O conjunto está bem mais adstrito à “filosofia natural”, ou, em versão mais moderna, à Ciência; mas não só. Euclides (6) debruça-se sobre uma ardósia pousada no chão e mede as dimensões de uma figura geométrica. O “pai da Geometria” rodeia-se de discípulos. Um pouco mais à direita, Zoroastro (7) discute os astros celestiais com o seu colega Ptolomeu (8). O diálogo é es- cutado por dois “modestos” sábios renascentistas: Rafael Sanzio (9), que nos fita, e, eventualmente, Sodoma (10).

Na escadaria central Diógenes de Sinope (11), ideal cínico do desapego aos bens materiais, em quietude, espalha o seu velho corpo despojado pelos degraus e lê.

\section{Os Pré-Químicos}

Ordem, regularidade, leis da Natureza... Como é constituída a matéria? Haverá uma substância primordial, um só elemento? E como deduzir a partir dele todas as coisas? $\mathrm{Ou}$ existirão muitos elementos diferenciados? Quais as qualidades do corpo vivo em oposição ao corpo inanimado? Será a matéria divisível até ao infinito? Afinal, qual é a natureza última das coisas? Eis as primeiras interrogações em que a razão conduziu o homem [9, 14-17].

\subsection{A ESCOLA JÓNICA}

A Jónia, antigo nome por que era conhecida uma região na costa sudoeste da Ásia Menor, detém o privilégio de ter albergado a primeira civilização helénica conhecida. A tradição indica ter sido em Mileto que floresceu a primeira escola filosófica, que teve como principais representantes Tales, o seu fundador, Anaximandro e Anaxímenes.

Tales ( $\approx 624-547$ a.C.) tinha uma postura “científica”, organizava as observações, reflectia sobre as causas dos fenómenos, previa efeitos sustentados, aplicava a informação. Tinha bons conhecimentos de Astronomia e de Matemática. Explicou o que seria um eclipse de Sol e imortalizado ficou pela atribuição que lhe é feita do teorema que detém o seu nome. Especulou sobre a origem da Terra e a sua evolução. Concluiu que a Água, e não qualquer desígnio sobrenatural, era o "elemento primordial”, a força geradora onde tudo se começa e tudo se continua.

A figura de Tales de Mileto não parece estar presente em “A Escola de Atenas”; pelo menos, nenhum estudioso fez

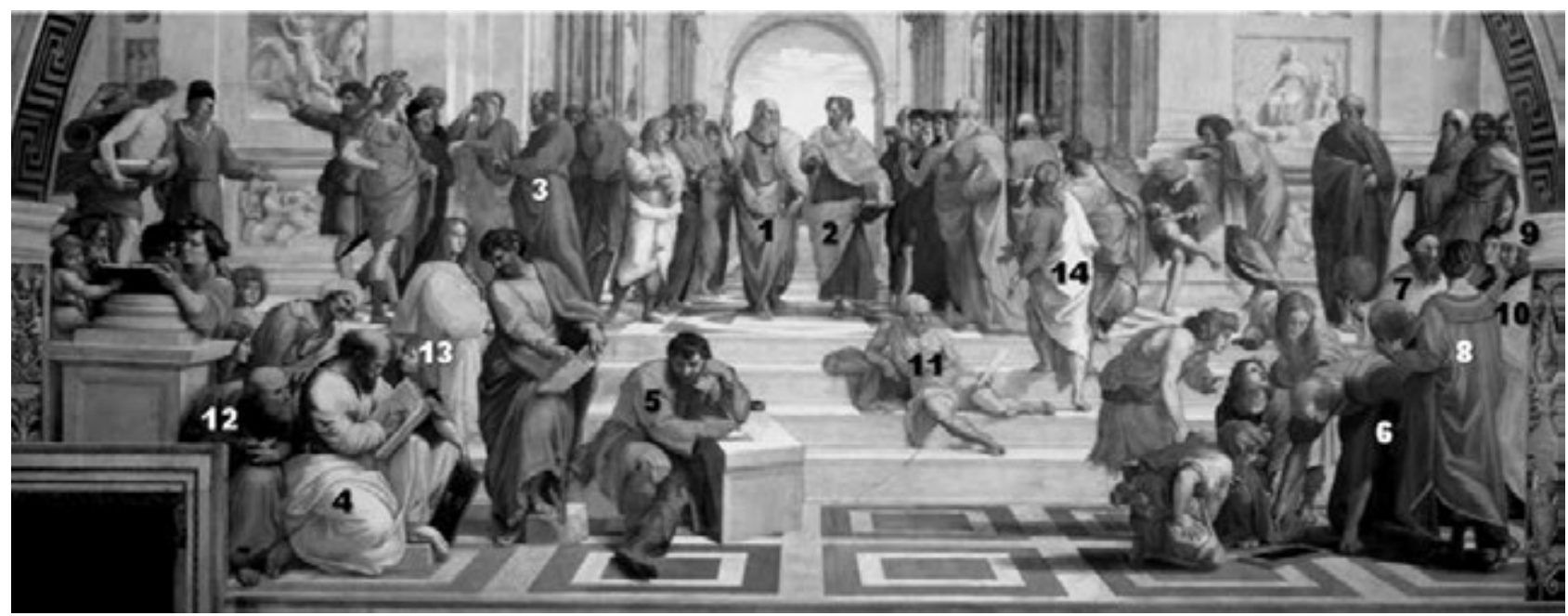

Figura 4 - Diagrama parcial de "A Escola de Atenas"

(1) Platão, (2) Aristóteles, (3) Sócrates; (4) Pitágoras; (5) Heráclito de Éfeso; (6) Euclides; (7) Zoroastro; (8) Ptolomeu; (9) Rafael Sanzio; (10) Sodoma; (11) Diógenes de Sinope; (12) Anaximandro; (13) Anaxágoras de Clazómenas; (14) Epicuro de Samos (ou Demócrito de Abdera) 
semelhante atribuição. Pode parecer estranho que um tão grande símbolo da sabedoria não surja no fresco, mas que, pelo contrário, o seu pupilo Anaximandro (12) seja uma das figuras presentes [13]. Podemos avançar uma eventual explicação. Anaximandro ( $\approx 610-547$ a.C.), ainda que adepto da visão naturalista de Tales, ficou muito mais próximo da divindade do que este. Renegando a Água como elemento primordial, uma vez que pode ter por oposto o seco, propõe uma "substância" infinita em quantidade e em qualidade, em extensão, no tempo e no espaço: o Apeiron, imortal e indestrutível, em permanente movimento e concepção. A partir do Apeiron ter-se-iam criado os pares antónimos calor e frio, seco e húmido. A ordem estabelece-se na Terra pela compensação cíclica dos opostos.

O rigor da investigação e da análise de dados, que nos faz assemelhar Tales a um homem moderno, perde-se um pouco com o seu discípulo. Anaximandro deixa-se levar pelas suas próprias especulações com uma forte componente de imprecisão; a sua prosa é poética, longe de uma escrita científica. Não é o Apeiron, oculto, uma forte aproximação ao mito, à divindade? O Papa Júlio II apreciaria, sem dúvida, esta explicação do Cosmos saído do Caos.

Anaxímenes ( $\approx 585-525$ a.C.) foi aluno de Anaximandro e, após analisar as propostas dos seus antecessores no que respeita ao elemento primitivo da matéria, renegou ambas. A sua opção recaiu no Ar, “elemento” que assume as qualidades com o movimento: o Ar soprado com a boca aberta é quente, saído dela como um assobio é frio. Podemos rir, mas uma coisa é certa, o retorno à observação e à experiência aí está. O Ar de Anaximandro é vital.

O Fogo foi para Heráclito de Éfeso ( $\approx 550-480$ a.C.) o primeiro elemento da Natureza. Desde a Pré-história, quando um raio cruzou os céus e uma fogueira acendeu, se sabia ser o Fogo um elemento transformador. As técnicas metalúrgicas e o sabor da carne assada eram demonstração suficiente!

Heráclito (5) tem lugar marcado, e marcante, na "Escola" de Rafael. Solitário, medita e escreve. Absorto nos seus pensamentos, renega os prazeres e o conforto que o mundo material lhe pode oferecer, no fresco tal como na sua vida real. É, provavelmente, o mais espantoso dos eruditos pré-socráticos - Rafael assim bem o entendeu. “Obscuro” e "Criador de enigmas” são alguns dos epítetos que indicam o seu nome.

Materialistas, racionais e, tendencialmente, ateus ou monoteístas, os pensadores da Escola Jónica preocupavam-se mais com o estudo da Natureza do que com a moral e a política. O mundo era dinâmico e as transformações dos elementos - Água, Ar, Fogo e depois Terra - o seu suporte. As inferências de carácter metafísico são refreadas e os processos científicos e técnicos "explicados”. As chamas sobem e as pedras descem, tendências opostas e necessárias cuja tensão entre si ilustra a própria estrutura do Universo. O grande mérito que o naturalismo jónico trouxe para a química primitiva foi a tentativa de responder de forma simples e concreta a questões fundamentais do quotidiano: De que é feito? Como é feito? Como funciona?

Podemos acrescentar que, hoje, muito pouco se aproveita em termos científicos do pensamento da Escola Jónica. Hoje, não se admite que um cientista seja puramente descritivo e se fique pelas qualidades. Mas foi um bom começo.

Deixemos de lado a nebulosidade mística pitagórica que envolveu números e quantidades, as expressões mais fundamentais da Matemática. Podemos conjecturar sobre o que é a Matemática, ciência das regularidades, dos padrões, das teorias, das demonstrações, da axiomática, da lógica formal... Certo é que, sem o conhecimento matemático aplicado não existiria Engenharia, Física, Química... Biologia, Medicina e Ciências Sociais.

\subsection{A Escola Pluralista}

Uno e múltiplo... Enquanto que os eleatas pugnaram pelo primeiro, numa intransigência absoluta, os pluralistas defenderam o segundo. A doutrina eleática distingue-se pela utilização austera do princípio da não-contradição como regra fundamental de coerência intelectual. Teve o seu período áureo com Parménides ( $\approx 520-$ ? a.C.), nascido em Eleia, cidade no sul de Itália. A sua doutrina, exposta em forma de poema épico, versa sobre o “ente” e os seus atributos, com sentimento religioso e discurso cintilante. A doutrina eleática criou debate e controvérsia. A Escola da Pluralidade ou Pluralista - Anaxágoras de Clazómenas (13), Empédocles de Agrigento e os atomistas Leucipo e Demócrito de Abdera - foi a sua principal adversária.

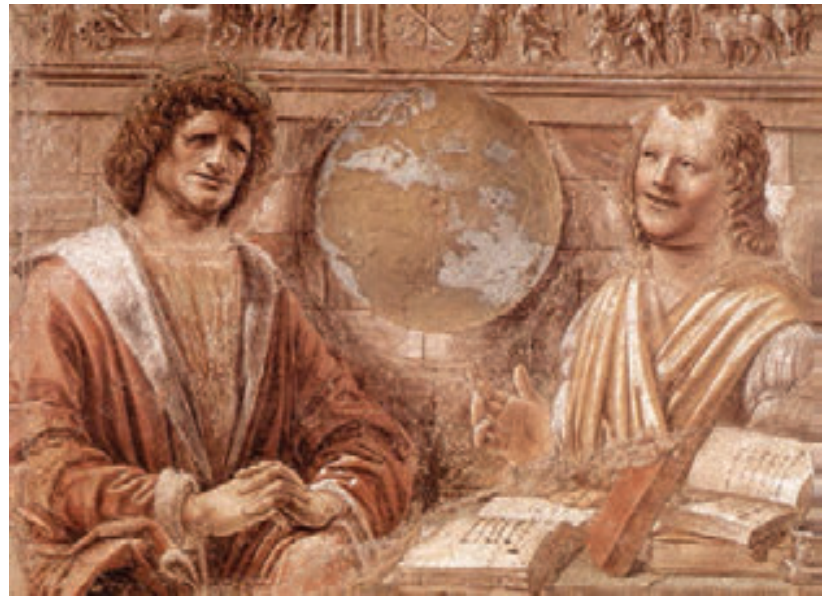

Figura 5 - "Heráclito e Demócrito” (1477), por Donato Bramante. Fresco do Palácio Panigarola, “Sala Del Baroni”, Pinacoteca di Brera, Milão

O que caracteriza a Escola Pluralista é o pensamento comum de que não existe um único princípio a partir do qual se pode explicar todo o Universo. Para Anaxágoras são as "sementes" em quantidade infinita, para Empédocles os quatro elementos como base constitutiva de toda a matéria, para Leucipo e o seu brilhante aluno Demócrito, os “átomos” e o “vazio” que tudo preenchem.

Anaxágoras ( $\approx 500-428$ a.C.) deixou a Ásia Menor por Atenas. Acreditava na existência de uma quantidade 
interminável de componentes da matéria e de qualidades sensíveis. Qualquer porção de matéria, dizia ele, era infinitamente divisível. Há aspectos nas suas doutrinas que se revestem de considerável importância na História da Química. O princípio da conservação da matéria, melhor se diria da matéria-energia, é atribuído a Antoine Lavoisier (século XVIII); todavia, por volta de 450 a.C., Anaxágoras afirmou que "nada nasce ou morre, mas apenas as coisas já existentes se recombinam, para depois se separarem”. A conservação, a síntese e a análise...

Para o filósofo tudo estava misturado com tudo, embora em doses diferentes conforme o artefacto. Restava-lhe um problema: como explicar que se ingerisse carnes e vegetais e que, no entanto, os ossos e os nossos órgãos, em geral, fossem tão diferentes dos nutrientes? E, tal como acontece com os seres vivos, o mesmo sucedia com muitas transformações na Natureza. Será, a seu ver, a divisibilidade e a redistribuição de múltiplos elementos as responsáveis pelas alterações que os sentidos e as sensações detectam. É a proporção dos diversos componentes nos objetos que nos fazem perceber uns e não notar os outros.

Em termos cosmogónicos, propôs que, desde o início dos tempos, todas as coisas já tivessem existência sob a forma infinitesimal, espalhadas por todo o Universo. Este "caldo” de spermata conteria de forma indistinguível miniaturas de plantas, de animais e, mesmo, de rochas e de minerais. $\mathrm{E}$ depois? Como chegar às formas dos dias de hoje? Anaxágoras, alérgico à existência de um panteão de deuses, cria então uma inteligência suprema a que chamou Nous, que significa Mente. O trabalho de Nous e de Movimento, inicialmente em turbilhão, teria formado agregados. A Terra, por exemplo, ter-se-ia a seu tempo desagregado do "caldo", assim como sementes dos seres vivos e dos seres inanimados nossos conhecidos e que na Terra vieram a "germinar”. Quem não vê nestas descrições as origens, filosóficas sem dúvida, ainda que fantasiosas, de uma teoria atómica científica, de uma Tabela Periódica de Elementos e de uma Panspermia, esta última tão amplamente defendida pelos químicos Jöns Berzelius (1779-1848), Hermann E. Richter (1808-1876), Hermann von Helmholtz (18211894), William Thomson (1824-1907; Lord Kelvin) e Svante Arrhenius (1859-1927; Prémio Nobel da Química em 1903) [18].

Anaxágoras, ao criar Nous, algo extremamente peculiar e influente, subtil agente possuidor de todo o conhecimento e poder, não se livra de ser um “cristão”, antes de Cristo. Rafael Sanzio e o Papa Júlio II assim o devem ter entendido, colocado que foi este "conhecedor das causas" em "A Escola de Atenas".

Empédocles ( $\approx 492-432$ a.C.), aristocrata de Agrigento, na Sicília, é uma figura controversa e multifacetada. A política e a poesia atraíam-no, assim como a Medicina e a observação cuidada dos fenómenos na Natureza. Toda a sua actividade foi desenvolvida entre o místico e o racional. Em “A Escola de Atenas”, Empédocles tem sido identificado, embora sem unanimidade, com um ou outro dos mais interessados ouvintes de Pitágoras. Mas fez trabalho sério que chegou até nós. As “raízes”, de qualidade inalterável e homogénea, são, a seu ver, em número de quatro: o Fogo, o Ar, a Água e a Terra. O Fogo era o elemento de Heráclito, o Ar de Anaxímenes e a Água de Tales... Criação e recriação a que juntou a Terra. Os fenómenos não mais seriam do que processos que misturam e trocam raízes. Ah, falta o Movimento! O motor necessário ao seu encontro, e desencontro, propõe ele, é o Amor (Philotés) e o Ódio (Neikos).

Que devemos reter da obra de Empédocles? Desde logo as grandes linhas da “Teoria dos Quatro Elementos” que Aristóteles advogará e desenvolverá, teoria esta que permanecerá quase inviolável no espírito da Química até finais do século XVIII. Do mesmo modo, para além da Antiguidade Clássica, o Período Medieval e mesmo o Renascentista compreenderá a síntese e a análise químicas tendo por base as atracções e repulsões entre "elementos", provocadas pelo amor e pelo ódio, respectivamente.

Pouco se sabe do pré-socrático Leucipo (séc. V a.C.), contemporâneo de Anaxágoras. O seu berço terá sido Mileto ou Abdera, onde fundou uma escola que se pode integrar na corrente filosófica geral da Pluralidade. É quase certo que a ele se deve a designação de “átomos” para nomear as partículas indivisíveis que propõe constituírem toda a matéria - átomos duros, densos e homogéneos, que ocupam espaço e têm forma e dimensão inalteráveis; indestrutíveis e em permanente movimento. São átomos filosóficos, sim, mas convém ter presente que nas teorias atómicas do filósofo e cientista francês Pierre Gassendi (1592-1655), do físico e matemático britânico Isaac Newton (1642-1727) e mesmo do químico e físico, igualmente britânico, John Dalton (1766-1844), mais de vinte séculos volvidos, os átomos científicos encontram quase a mesma definição!
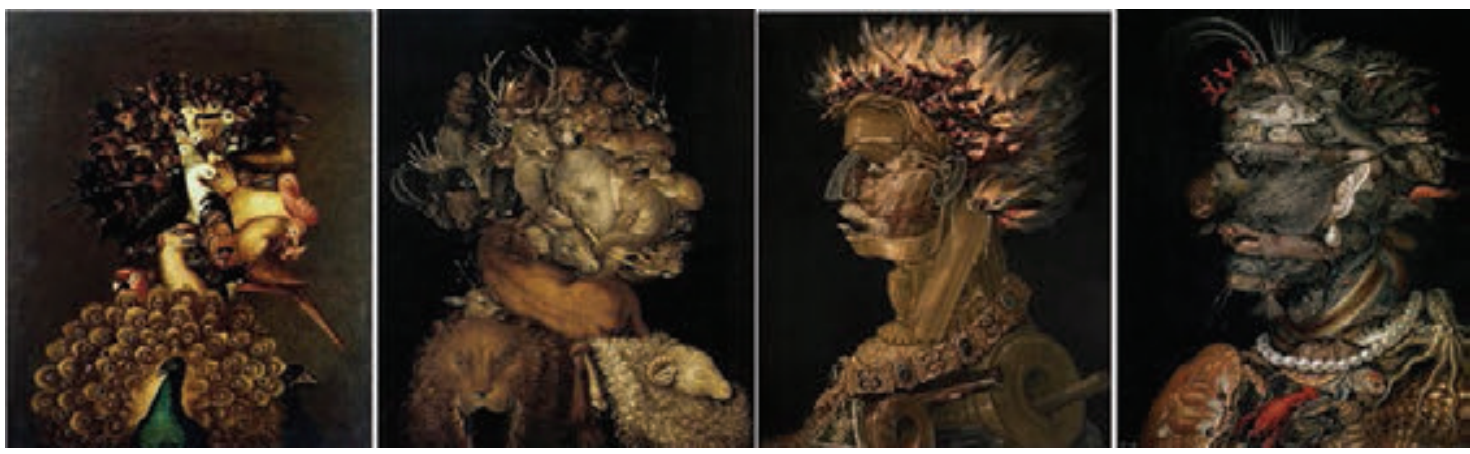

Figura 6 - “Os Quatro Elementos” (1566), por Giuseppe Arcimboldo Ar, Terra, Fogo e Água 
Com a existência de átomos e vazio, Leucipo responde a Tales: Qual é a natureza última das coisas? Vazio? Que horror! Leucipo, e depois Demócrito, devem ter estarrecido os demais filósofos e não-filósofos do seu tempo para os quais o Universo era cheio - era uma questão de bom senso!

Os átomos e o vazio são complementares; onde existem uns não pode existir o outro e, no seu conjunto, compõem o Universo. Estes átomos são feitos da mesma essência, mas diferem no "ritmo", no "contacto” e na "rotação”. O "ritmo" relaciona-se com a sua configuração e dimensão, o "contacto" com a formação de substâncias mais complexas, os objectos, e a "rotação” com a orientação que tomam no espaço. Tudo se explica por formas e movimentos; e um pouco de vazio para sedimentar o modelo.

O Atomismo manifesta uma renovação do naturalismo jónico, dando primazia à determinação de “construções” em relação à descrição de géneses, embora, em última análise, tente atingir estas por interpretação daquelas. $\mathrm{O}$ afastamento da realidade sensível, afim ao senso comum, e a busca de dados conclusivos extraídos da observação e da experimentação define um pensamento que se deseja claro e consistente. O êxito nem sempre foi garantido. Muito longe se estava ainda de conceber o quanto o senso científico se pode afastar do senso comum!

Demócrito (460-370 a.C.), de família abastada, escreveu muito e viajou muito. Acreditou piamente no Atomismo. A partir de átomos e vazio ele próprio veio a desenvolver a ideia de que combinações simples produziriam a variedade das coisas até ao infinito. O movimento dos átomos criaria vórtices (remoinhos) no espaço e, em consequência desta centrifugação cósmica, os átomos maiores e/ou mais lentos ficariam no centro, enquanto que os mais leves e mais velozes seriam atirados para a periferia. Assim explicava a formação da Terra e da sua envolvente. E, para mais, confiava na existência de muitas Terras, muitos Sóis e muitas Luas concebidos de igual modo [18]. Não é surpreendente a estreita semelhança com os modelos correntes do Universo, de formação das estrelas e do seu séquito de planetas? Herança? Evidentemente, sim. Os átomos, as atracções, as repulsões, os vórtices, são conceptualizações qualitativas da matéria e da formação da matéria. Mostram como a imaginação é fértil, mas pode ser enganadora. A Ciência ensina-nos isso mesmo: não devemos renegar a imaginação intelectual; todavia, devemos submetê-la à reflexão, à prova, à objectivação. Nós somos os descendentes, indirectos, da Antiguidade Clássica.

Demócrito, empolgado, levou o seu modelo para além de limites razoáveis. Nem só os “objectos” passaram a ser formados por átomos e vazio. Também as sensações, os pensamentos e os sentimentos... E a morte? A morte vinha quando o equilíbrio dinâmico de troca de átomos com o exterior se desorganizava e os minima da alma se ausentavam, exteriorizando-se ao corpo.

Platão, o filósofo das ideias, manifestou hostilidade em relação a certos conceitos de Demócrito e ao seu embrião de explicação do Mundo mecanicista. Multiplicidade, e não unicidade, de partículas invisíveis, onde apenas a diferenciação de forma seria suficiente para surtir efeito? Movimentos espontâneos, choques? Ausência de causalidade, de finalidade cósmica? E os números, onde estão? Que absurdo, terá pensado Platão, que nem uma só vez na sua obra mencionará Demócrito. Aristóteles também não gostou. Epicuro de Samos (341-270 a.C.), todavia, cerca de cem anos mais tarde, irá retomar nos seus escritos a doutrina do Atomismo como se sua fosse, e "ignorar" a existência de Leucipo.

Não é claro se Demócrito de Abdera está representado em “A Escola de Atenas”. Provavelmente não está e, pelo que atrás descrevemos, não é difícil justificar a sua ausência. No entanto, têm-se verificado certa recorrência de estudiosos para tentarem a sua identificação com várias figuras - a "disputa" mais frequente surge, inevitavelmente, com Epicuro de Samos (14).

\subsection{ARIstóteles}

Aristóteles (384-322 a.C.) nasceu em Estagira, na Trácia, colónia grega situada na costa do Mar Egeu. Estudou em Atenas, na Academia de Platão.

Em 335 a.C., Aristóteles criou a sua própria escola. Chamou-se "Liceu” ou "Escola Peripatética", nome este derivado dos caminhos cobertos nas imediações. Aristóteles gostava de dar as suas aulas passeando ao longo dos perípatos. Tal como a Academia, o Liceu dispunha de salas para conferências (aulas), biblioteca e residências para alunos; mas o Liceu dispunha ainda de laboratórios. Aí se fazem experiências, obra nova em pré-Ciência química, física e biológica.

Aristóteles ainda ia mais longe do que Platão, não acreditava na existência de "átomos" e, muito menos ainda, que eles tivessem formas geométricas diferenciadas e que, entre eles, existisse “vazio”. O espaço aristotélico é cheio, contínuo e infinitamente divisível. O número quatro parece ter sido um número “mágico” para Aristóteles. A matéria seria formada a partir de quatro elementos primordiais - os elementos de Empédocles, o Fogo, o Ar, a Água e a Terra - embora assumisse que todos eles tinham um substrato único não isolável [19]. Aos quatro elementos correspondiam-se, duas a duas, quatro qualidades primárias: quente, frio, seco e húmido. Assim, por exemplo, o Fogo era quente e seco e a Água fria e húmida. Os elementos tinham “tendências naturais”. A Terra e a Água, se não encontrassem oposição, cairiam para o centro do Universo (o nosso planeta), enquanto que o Fogo e o Ar se elevavam para espaços superiores. A chuva desce e as chamas sobem... para os seus lugares naturais [20].

Observemos, de novo, o par central de "A Escola de Atenas”, Platão (1) e Aristóteles (2). Rafael Sanzio fez o que devia ser feito: mostrou como o igual pode ser tão diferente. A palma da mão de Aristóteles, de castanho-Terra e azul-Água vestido, virada para o chão, simboliza a visão 
realista que o "Professor” tinha da Natureza. Platão, por seu lado, com a mão apontando o céu, simboliza a essência mística que ele atribuía ao Universo. O "Mestre” veste de Ar e Fogo, com a sua túnica violeta pálido e manto vermelho intenso. Não, Rafael não os coloriu apenas em função da sua arte, coloriu-os também em função de um signo de dicotomia que marcará os milénios seguintes na via do conhecimento das causas e dos princípios do mundo material [21].

\section{REFERÊNCIAS}

[1] "Raphael's School of Athens”, M. Hall (ed.), Cambridge University Press, Cambridge, 2000

[2] “The Cambridge Companion to Raphael”, M.B. Hall (ed.), Cambridge University Press, Cambridge, 2005

[3] M. Carminati, "Raphael - The School of Athens", 24 ORE Cultura, Milão, 2012

[4] C.L. Joost-Gaugier, "Raphael's Stanza della Segnatura - Meaning and Invention”, Cambridge University Press, Cambridge, 2002

[5] A.F. Forcellini, "Raphael - A Passionate Life”, Polity Press, Cambridge, 2013

[6] G.I. Spadaro, “The Esoteric Meaning in Raphel's Paintings”, Lindisfarne Books, Great Barrington, 2006

[7] Palavras utilizadas por Giovanna della Rovere, cunhada do Papa Júlio II e mãe do futuro Duque de Urbino, Francesco Maria, numa carta de recomendação endereçada a Piero Soderini, a autoridade máxima do estado de Florença, em 1503

[8] “A Disputa” é o nome comum atribuído ao primeiro fresco realizado por Rafael: "A Discussão do Sacramento Divino" ou “A Discussão do Santíssimo Sacramento”, obra dedicada ao debate de teólogos sobre princípios fundamentais da fé cristã, como sejam, o dogma da Santíssima Trindade e o mistério da transubstanciação.

[9] A Filosofia Pagã - Do séc VI a.C. ao séc. III d.C. in “História da Filosofia, Ideias, Doutrinas”, F. Châtelet (dir.), Publicações D. Quixote, Lisboa, 1983
[10] “The Greek World”, A. Powell (ed.), Routledge, Nova Iorque, 1995

[11] G. Garrigues, The Journal of Speculative Philosophy 13 (1879) 406-420

https://archive.org/details/jstor-25667781 (acedido em 1402-14)

[12] H.B. Gutman, Journal of the History of Ideas 2 (1941) 420429

http://www.jstor.org/discover/10.2307/2707020?uid=373888 0\&uid $=2129 \&$ uid $=2 \&$ uid $=70$ \&uid $=4 \&$ sid $=21103046795707$ (acedido em 14-02-14)

[13] Outra hipótese razoável de identificação do velho homem, indica-o como sendo Arquitas de Tarento (428-347 a.C.), matemático, filósofo e estadista da Escola Pitagórica, grande amigo de Platão.

[14] J. Brun, “Os Pré-Socráticos”, Edições 70, Lisboa, 1991

[15] “The Cambridge Companion to Early Greek Philosophy”, A.A. Long (ed.), Cambridge University Press, Cambridge, 1999

[16] R. Gonçalves-Maia, “Ciência, Pós-Ciência, Metaciência - Tradição, Inovação e Renovação”, Editora Livraria da Física, São Paulo, 2011

[17] R. Gonçalves-Maia, “O Legado de Prometeu - Uma Viagem na História das Ciências”, Escolar Editora, Lisboa, 2006

[18] H.L.S. Maia, K.G. Orrell e I.V.R. Dias, “Origin of Life Recent Contributions to a Scientific Model”, Internet Archive, 2010

http://www.archive.org/details/OriginOfLife (acedido em 14-02-14)

[19] Aristóteles considerou ainda a existência de um quinto elemento, a quinta essência pura e divina, que entraria na composição das esferas celestes e dos corpos celestes, estrelas e planetas

[20] C. Natali, “Aristotle - His Life and School”, Princeton University Press, Princeton, 2013

[21] R. Gonçalves-Maia, “CAUSARUM COGNITIO - O Conhecimento das Causas. A Escola de Rafael Sanzio”, em preparação

\section{Actualidades Científicas}

\section{CÁlCULOS TEÓRICOS PREVÊEM A EXISTÊNCIA DE N 8}

O nitrogénio pode formar um cristal molecular de fórmula $\mathrm{N}_{8}$ a baixas temperaturas, de acordo com cálculos efectuados por investigadores da Hebrew University of Jerusalem, Israel, e da University of Southern California, EUA, usando a teoria do funcional da densidade. A estrutura cristalina hipotética, que foi descoberta acidentalmente, consiste em moléculas de $\mathrm{N}_{8}$ contendo uma combinação de ligações simples, duplas e triplas.

Nos últimos anos tem-se pesquisado novas moléculas e iões poliatómicos de nitrogénio, tendo os estudos teóricos desempenhado um papel importante na exploração das condições de existência de diferentes espécies de nitrogénio metastáveis. A principal motivação para estes estudos reside no facto destas espécies poderem potencialmente libertar grandes quantidades de energia quando se decompõem em $\mathrm{N}_{2}$, a sua forma mais estável.

(adaptado de http://www.rsc.org/chemistryworld/2013/12/calculations-predict-stable-eight-nitrogen-molecule e de B. Hirshberg et al., Nat. Chem. 2013, DOI: 10.1038/nchem.1818)

Paulo Mendes

(pjgm@uevora.pt) 


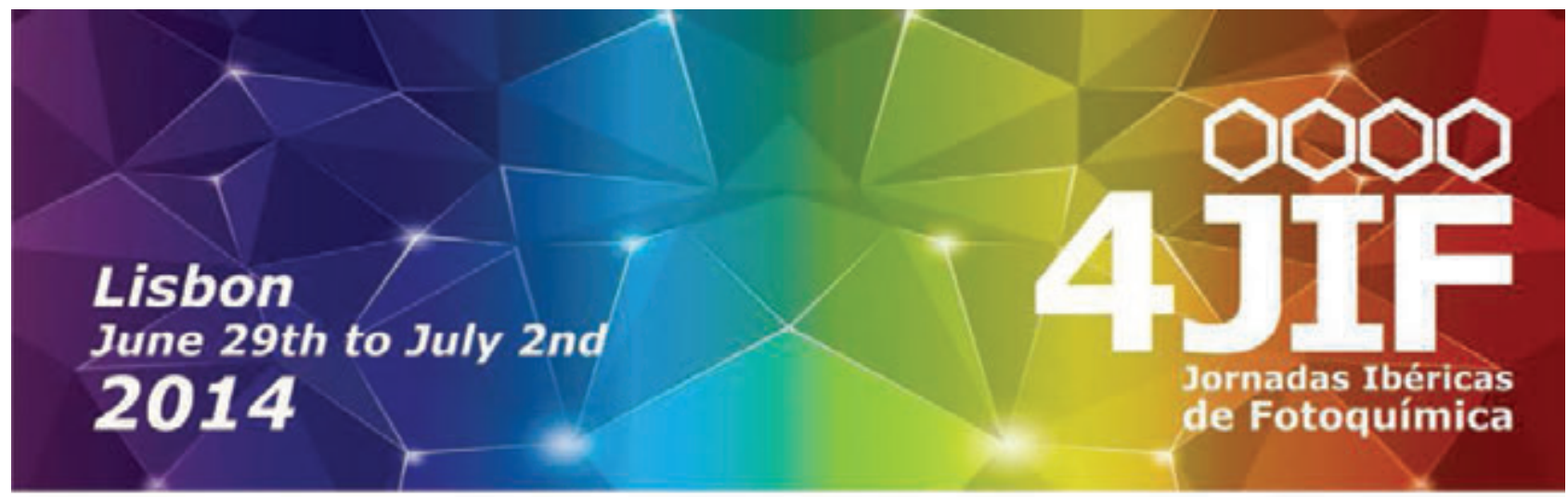

O Grupo de Fotoquímica convida todos os sócios da SPQ para as 4as Jornadas Ibéricas de Fotoquímica (4'JIF) organizadas pela Sociedade Portuguesa de Química e pela Real Sociedade Espanhola de Química.

No espírito das edições anteriores (Santiago de Compostela 2003, Faro 2007 e Granada 2011), as 4'JIF terão como tema central a fotoquímica, abordando no entanto as áreas de interface com a fotofísica, fotobiologia, síntese, química analítica, e materiais.

\section{Plenárias confirmadas}

Luisa de Cola

Universidade de Estrasburgo

Julia Pérez-Prieto

Universidade de Valencia

Hugh Burrows

Universidade de Coimbra

\section{Orais Convidadas confirmadas}

Ermelinda Maçôas, Instituto Superior Técnico

Uwe Pischel, Univ. de Huelva

Jorge Parola, Univ. Nova de Lisboa

Jordi Hernando, Univ. Autonoma de Barcelona

Carlos Serpa, Univ. de Coimbra

Eugenio Vásquez, Univ. Santiago de Compostela

\section{Data Limite para a Submissão de Resumos: 15 de Abril}

Orais a seleccionar dos resumos submetidos.

\section{Data Limite para Registo: $\mathbf{2 5}$ de Maio}
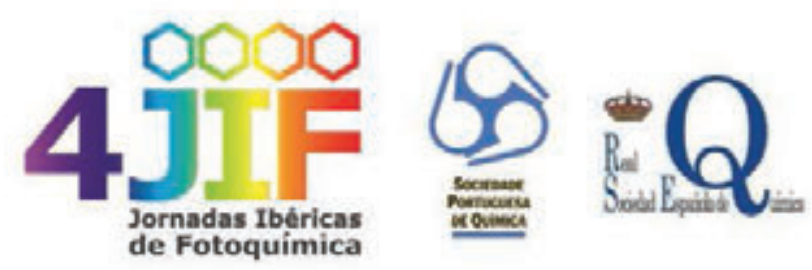

http://4jif.eventos.chemistry.pt

\section{4jif@chemistry.pt}




\section{FAÇA-SE FOGO! - A INVENÇÃO DOS FÓSFOROS}

\section{OS FÓSFOROS MODERNOS}

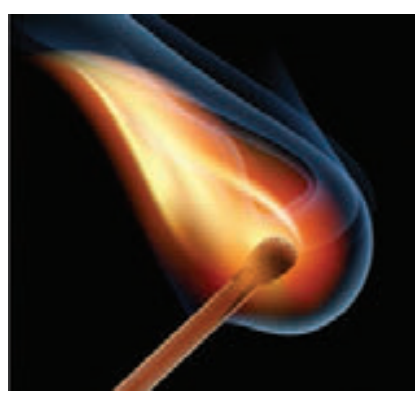

Os antepassados dos humanos terão conseguido o controlo do fogo há mais de 500 mil anos mas a capacidade da sua produção só a terão atingido centenas de milhares de anos mais tarde, no Neolítico. Para isso recorreram à fricção de pedaços de madeira e à percussão do sílex sobre a pirite (e mais tarde sobre o aço). O sílex e o aço, curiosamente, constituem ainda hoje a "pedra" dos isqueiros. Entre outros métodos arcaicos de fazer fogo destacam-se também o êmbolo de fogo asiático e, posteriormente, a concentração dos raios solares através de lentes [1,2].

Os fósforos modernos são constituídos por duas partes fundamentais: a cabeça (que inicia o processo de combustão) e um palito de madeira ou de cartão ao qual se propaga a chama inicial. Os palitos são previamente tratados com uma solução de fosfato de amónio ou bórax e uma das suas extremidades é mergulhada em parafina líquida, para aumentar a inflamabilidade, após o que é coberta com uma pasta constituída maioritariamente por cerca de $50 \%$ de clorato de potássio, $4 \%$ de enxofre, $1 \%$ de dicromato de potássio, $10 \%$ de gelatina, $10 \%$ de óxido de zinco e $15-$ $20 \%$ de vidro moído. O clorato de potássio fornece o oxigénio necessário para a ignição e combustão; o enxofre é o principal material combustível; o dicromato de potássio actua como agente oxidante; o óxido de zinco ajuda a controlar a velocidade de propagação da chama e a gelatina é o agente ligante da mistura. O vidro moído actua como ligante dos componentes fundidos. O fosfato de amónio ou o bórax destinam-se a extinguir a incandescência do palito assim que o fósforo se apaga. As cabeças dos fósforos que acendem sobre qualquer superfície contêm ainda trissulfureto de tetrafósforo $\left(\mathrm{P}_{4} \mathrm{~S}_{3}\right)$ para aumentar a sensibilidade à ignição sobre uma superfície áspera. Os constituintes da "lixa” da caixa de fósforos são normalmente o fósforo vermelho, misturado com vidro moído, corantes e cola.

O calor desenvolvido pela fricção, no acto de riscar o fósforo, converte o fósforo vermelho contido na lixa no seu alótropo branco, o qual entra em ignição incendiando a cabeça. Trata-se de um conjunto complexo de processos físicos e químicos que começa com uma reacção no estado sólido, iniciada pelo calor da fricção, e que é propagada por uma série de reacções exotérmicas. A energia libertada depende sobretudo da composição química da cabeça do fósforo e da sua formulação. A temperatura da chama inicial varia entre 1350 e $1950{ }^{\circ} \mathrm{C}$ atingindo um valor constante de $1500{ }^{\circ} \mathrm{C}$ durante a combustão do fósforo [2].

\section{A DESCOBERTA DO FÓSFORO}

A descoberta do fósforo, em 1669, pelo alemão Hennig Brand, veio permitir ao Homem fazer fogo por outros meios que não os mecânicos. Brand, um mercador e alquimista de Hamburgo, após muitas noites de destilações sucessivas de centenas de litros de urina, obteve uma pequena quantidade de um material ceroso desconhecido que brilhava na escuridão. Chamou-lhe “fogo frio” [3]. Não era, todavia, o material que procurava; os seus esforços tinham sido acalentados pela esperança de obter um líquido que transmutasse a prata em ouro. Achou, apesar de tudo, que aquela substância nova seria interessante pois, para além da luminosidade que emitia, ardia vigorosamente quando era sujeita a ligeiro aquecimento ou fricção. Depois de várias peripécias, e de um pequeno punhado de dinheiro, Brand revelou o segredo da obtenção do seu "fogo frio”. Assim, o fósforo (que em grego significa "portador de luz”) tornou-se progressivamente conhecido, causando assombro e excitação um pouco por toda a Europa. Os seus preços eram elevadíssimos pois era obtido em quantidades ínfimas (eram necessários dois barris de urina - aproximadamente $500 \mathrm{~L}$ - para obter cerca de 30 g) [4].

Robert Boyle (Figura 1), que também obtivera fósforo a partir do aquecimento do fosfito de sódio, em 1680 aplicou-o em pequenas quantidades entre as pregas de um papel áspero, conseguindo que a chama obtida fizesse arder palitos de madeira com uma cabeça de enxofre [2,4]. Estes terão sido os primeiros verdadeiros fósforos mas na época não constituíram mais do que uma mera curiosidade por não serem práticos e o fósforo ser muito dispendioso.

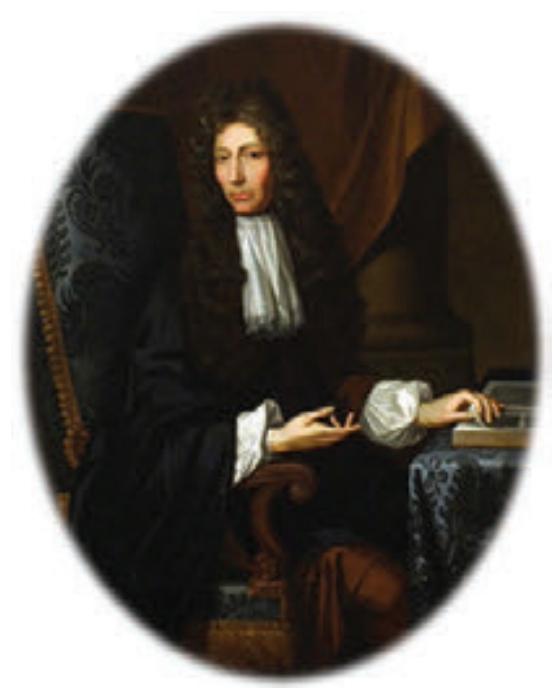

Figura 1 - Robert Boyle (1627-1691)

Assim, após o furor inicial, o fósforo foi progressivamente caindo no esquecimento. A sua capacidade de gerar fogo só seria recuperada cerca de 150 anos mais tarde, com a sua inclusão nos fósforos de fricção. Na década de 80 do séc. 
XVIII, contudo, foram desenvolvidos alguns dispositivos de obtenção de chama baseados neste elemento. Destes, destaca-se a “vela fosfórica” (ou “fósforo etéreo”) introduzida em França em 1781. Consistia num tubo de vidro de $10 \mathrm{~cm}$, selado, contendo uma fina tira de papel encerado, com a extremidade em franjas, e fósforo no fundo. O tubo, que na extremidade superior tinha um círculo marcado a diamante, era colocado em água quente para fundir o fósforo, impregnando assim o papel. Sempre que era necessária uma chama abria-se o tubo pelo círculo da extremidade e retirava-se o papel que instantaneamente se inflamava $[2,4]$.

\section{DISPOSITIVOS GERADORES DE CHAMA}

A arte de fazer fogo continuaria por muitos anos a ser um trabalho árduo apesar das múltiplas invenções que tentavam obviar o problema. São dignas de menção as técnicas que recorriam ao uso de materiais pirofóricos sem fósforo. Estes materiais, quando finamente divididos inflamam-se por exposição ao ar, razão por que têm de ser mantidos em ampolas de vidro. Sempre que se quisesse obter uma chama bastava quebrar o vidro. Das várias receitas complexas que nos chegaram citam-se as que referem a preparação de materiais pirofóricos recorrendo a compostos como o alúmen ou o azul da prússia [4]. Foram igualmente desenvolvidos vários tipos de bombas pneumáticas ("seringas de fogo" - Figura 2A), cuja compressão do ar fazia arder a mecha contida no seu interior [2].

Entre 1775 e 1830 foram inventadas várias lâmpadas electropneumáticas, baseadas no princípio da ignição de uma pequena corrente de hidrogénio por uma faísca oriunda de um pedaço de breu (resina residual da destilação da terebintina) electricamente carregado. Uma variante destes dispositivos foi a lâmpada de Volta (Figura 2B) [2].
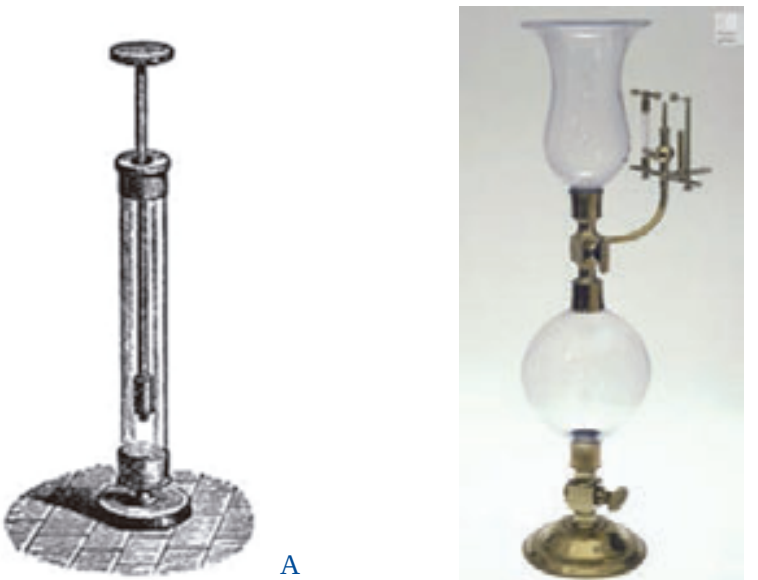

B

Figura 2 - (A) “Seringa de fogo” do séc. XIX, em vidro, com um êmbolo ao qual se aplicava uma mecha de um material facilmente inflamável (normalmente fibras vegetais sujeitas a uma prévia combustão incompleta ou um material esponjoso obtido do fungo Fomes fomentarius). (B) Lâmpada de Volta (circa 1790)

A partir de 1780 as casas dos ricos puderam contar com uma variedade de palitos de ignição por via química. Um dos inventos mais práticos e úteis foi a "caixa de luz instantânea”, inventada pelo francês Jean Chancel em 1805.
Esta caixa metálica continha um pequeno frasco de ácido sulfúrico concentrado e palitos de madeira de cedro com uma cabeça constituída por uma mistura de clorato de potássio, açúcar e uma goma ligante. Para iniciar o fogo, mergulhava-se um palito no ácido que ao libertar $\mathrm{HClO}_{3}$ oxidava exotermicamente o açúcar, uma reacção previamente descoberta por Claude Berthollet [4,5]. O aperfeiçoamento deste método veio a culminar em 1828 com a invenção do “fósforo Prometeu” pelo inglês Samuel Jones. Tratava-se de uma pequena cápsula de vidro hermeticamente selada, cheia de uma solução de ácido sulfúrico colorida com índigo, revestida exteriormente por uma mistura de clorato de potássio, açúcar e um material ligante. Esta cápsula encontrava-se no interior de um rolo de papel idêntico ao dos cigarros. Assim que se partia o vidro com recurso a um pequeno alicate (ou aos dentes do utilizador!) o papel começava a arder (Figura 3) [2,4].

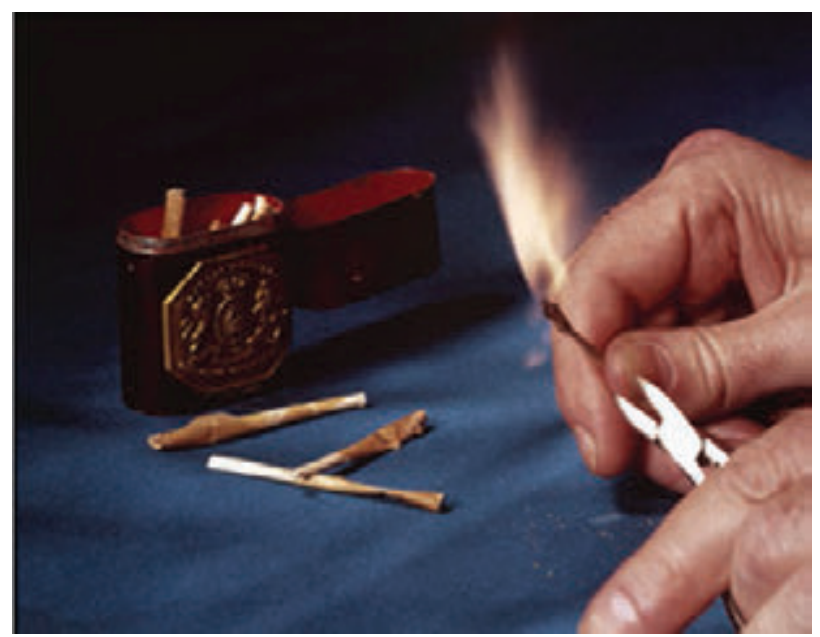

Figura 3 - "Fósforos Prometeu”

A tentativa de obter algo que produzisse facilmente lume por fricção teve um momento alto em Inglaterra em 1826, pelas mãos do farmacêutico John Walker, que criou as "Luzes de fricção", uns palitos antepassados dos modernos fósforos (apesar de não conterem fósforo), que se incendiavam quando esfregados entre dois pedaços de papel areado. Também na sua composição entrava o clorato de potássio (com sulfureto de antimónio, goma e amido). Nunca patenteou a sua invenção e, em 1830, Samuel Jones decidiu copiá-los e vendê-los, chamando-lhes "Luciferes”. Foram os primeiros "fósforos" a ser vendidos em pequenas caixas de cartão rectangulares. Tornaram-se tão populares que ainda hoje, em países como a Holanda e a Bélgica (Flamenga), "lucifer" significa fósforo de fricção [4].

A capacidade destes palitos para originar uma chama utilizável era todavia relativamente reduzida, o que levou a que o fósforo branco passasse finalmente a ser introduzido como componente activo. Tal ficou a dever-se ao francês Charles Marc Sauria, que em 1830 o adicionou a uma formulação idêntica à dos “Luciferes”. Estava assim inventado o verdadeiro fósforo de fricção [6]. Por volta de 1835 também os norte-americanos usavam já o fósforo no fabrico de fósforos de fricção encontrando-se os métodos anteriores em pleno declínio. 


\section{FóSFOROS DE SEGURANÇA}

Apesar do perigo associado à grande inflamabilidade do fósforo branco e à sua elevada toxicidade, este foi até meados do século XIX, porém, a única forma alotrópica disponível em quantidades compatíveis com a manufactura dos fósforos.

A partir de 1839 registaram-se múltiplos casos de funcionários da indústria fosforeira que desenvolviam osteonecrose da mandíbula devido à constante exposição ao fósforo branco $[7,8]$. Foram também várias as vítimas mortais da ingestão de cabeças de fósforos. Esta situação só cessaria na Europa a partir de 1906, quando a Convenção de Berna proibiu o fabrico e a comercialização de fósforos contendo fósforo branco. Os EUA restringiram a partir de 1913, pela via fiscal, a sua produção e importação [5].

Em 1847 o austríaco Anton Schrötter von Kristelli (Figura 4) anunciou a obtenção do fósforo vermelho a partir da exposição do alótropo branco à luz solar sob atmosfera inerte e igualmente por aquecimento a $250^{\circ} \mathrm{C}$. Na verdade, Jöns Jacob Berzelius já anteriormente tinha referido a existência de uma outra forma alotrópica do fósforo, obtida pela exposição do fósforo branco à luz. Por outro lado, alguns químicos consideravam que a forma vermelha se tratava de um óxido de fósforo [9].

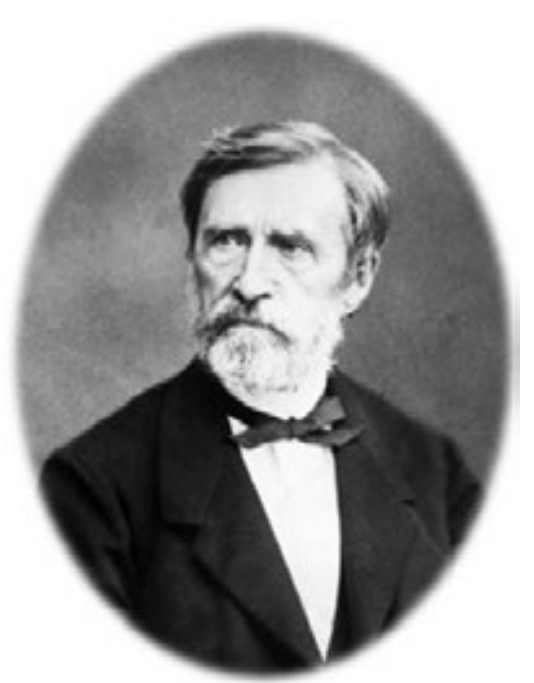

Figura 4 - Anton Schrötter von Kristelli (1802-1875)

Ao estudar as propriedades do alótropo vermelho, Anton Schrötter verificou que este podia ser mantido exposto ao ar sem reagir com o oxigénio; era também menos higroscópico que a forma branca e quando misturado com clorato de potássio detonava produzindo luz embora a sua reactividade fosse menor. Todas estas características, a que se somava o facto de não ser tóxico, fizeram dele o candidato ideal para substituir o fósforo branco na indústria fosforeira.

Não tardou muito para que a indústria química se interessasse pelo método de Schrötter e, a partir de 1851, pelas mãos de Arthur Albright, a cidade de Birmingham dispôs de uma unidade industrial de produção de fósforo vermelho.
O primeiro “fósforo de segurança” foi patenteado em 1844 pelo sueco Gustaf Erik Pasch. De acordo com o método que preconizou o fósforo era colocado unicamente na superfície rugosa no exterior da caixa, diminuindo assim o risco da ignição espontânea. Adicionalmente usou o fósforo vermelho, o qual acreditava tratar-se de um óxido de fósforo. Este conceito foi posteriormente aperfeiçoado pelos dois irmãos suecos Johan Edvard e Carl Frans Lundström que, em 1855, apresentaram com grande sucesso os seus "fósforos de segurança” na Exposição Mundial de Paris [7].

Na segunda metade do século XIX apareceram diversos tipos de fósforos que se podiam acender sobre qualquer superfície mas um dos contributos mais importantes da história da indústria fosforeira deveu-se aos franceses Henri Sévène e Emile David Cahen: em 1898 introduziram o trissulfureto de tetrafósforo na composição dos fósforos. Este composto, preparado pela primeira vez pelo francês George Lemoine em 1864, para além de não ser tóxico, oferece resistência adicional à humidade. É ainda hoje o agente de ignição dos fósforos que se acendem ao serem riscados sobre qualquer superfície [8].

\section{Curiosidades}

Charles Darwin referiu os "fósforos Prometeu" em The Voyage of the Beagle (Londres, 1839). A obra relata a segunda expedição de levantamento topográfico do navio HMS Beagle (1831-1836), que possibilitou a Darwin efectuar importantes investigações na área da biologia, geologia e antropologia.

A primeira máquina de produção de fósforos apareceu em Massachusetts (EUA) em 1851. Em 1863 os norte-americanos Anson e Ebenezer Beecher patentearam um processo de fabrico mecânico de fósforos em larga escala que esteve em uso até 1888, ano em que Ebenezer Beecher inventou uma máquina automática de produção em série (Figura 5) [10].

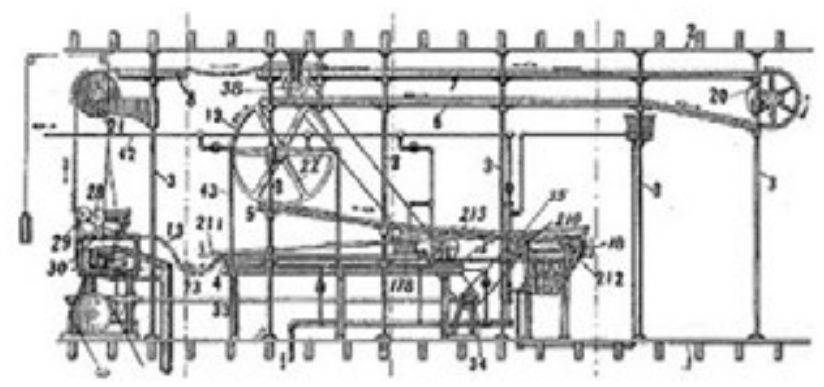

Figura 5 - Máquina automática de Ebenezer Beecher (1888) para a produção de fósforos em série

Em 1889 o norte-americano Joshua Pusey, um apreciador de charutos que achava demasiado volumosas as caixas de fósforos, principalmente se as tinha de transportar no bolso do smoking, inventou as bem conhecidas carteiras de fósforos de papel. Chamou-lhes "Flexíveis"; tinham a particularidade de poderem ser encontradas no escuro porque tinham uma marca pintada com tinta luminescente.

No entanto, a sua aceitação pelo público só se deu a partir de 1897, no seguimento de uma campanha publicitária le- 
vada a cabo pela Mendelson Opera Company, que as utilizou para anunciar a abertura da temporada em Nova Iorque (Figura 6) [2]. Afinal de contas nada muito diferente do que fazem actualmente os restaurantes e bares.

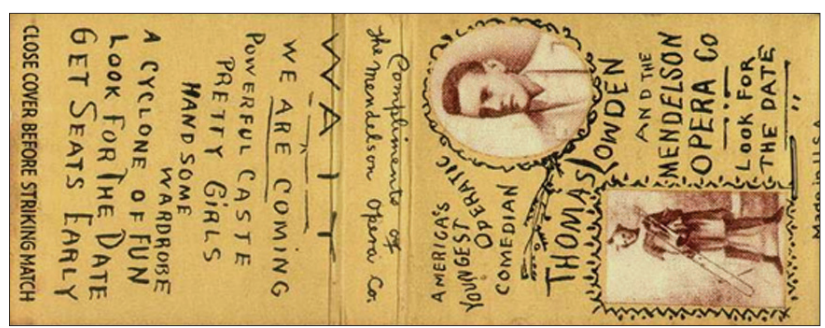

Figura 6 - Imagem de uma das primeiras carteiras de fósforos

\section{REFERÊNCIAS}

[1] K.R. Williams, J. Chem. Educ. 79 (2002) 408-410

[2] J. Wisniak, Indian J. Chem. Technol. 12 (2005) 369-380

[3] M.E. Weeks, J. Chem. Educ. (1933) 302-306

[4] M.F. Crass, J. Chem. Educ. 18 (1941) 116-120

[5] K.R. Williams, J. Chem. Educ. 79 (2002) 540-542

[6] M.F. Crass, J. Chem. Educ. 18 (1941) 277-282

[7] M.F. Crass, J. Chem. Educ. 18 (1941) 316-319

[8] M.F. Crass J. Chem. Educ. 18 (1941) 428-431

[9] M. Kohn, J. Chem. Educ. 21 (1944) 522-524

[10] M.F. Crass, J. Chem. Educ. 18 (1941) 380-389

João Paulo André (jandre@quimica.uminho.pt)

\section{Actualidades Cientifica}

\section{FORMA CRISTALINA IÓNICA DO AMONÍACO}

Um grupo de investigadores mostrou que quando o amoníaco é sujeito a uma pressão muito elevada forma um sólido iónico cristalino. Esta mudança foi prevista pela primeira vez em 2008 por cálculos teóricos, mas até agora nunca tinha sido demonstrada experimentalmente.

Uma equipa liderada por S. Ninet e F. Datchi do Institut de Minéralogie et de Physique des Millieux Condensés, em França, demostrou recentemente que a temperaturas acima de $750 \mathrm{~K}$ e pressões superiores $60 \mathrm{GPa}$, as moléculas se dissociam para formar uma fase superiónica composta por $\mathrm{NH}_{3}, \mathrm{NH}_{4}^{+}$e $\mathrm{NH}_{2}^{-}$que se comporta ao mesmo tempo como um sólido cristalino e um líquido. Em 2008, estudos teóricos já tinham previsto a existência, a baixas temperaturas e pressões elevadas, de uma fase contendo camadas alternadas de iões $\mathrm{NH}_{4}^{+}$e $\mathrm{NH}_{2}^{-}$.

Agora, Ninet e Datchi descobriram fortes evidências experimentais que suportam esta teoria sujeitando $\mathrm{NH}_{3}$ a pressões elevadas (194 GPa) à temperatura ambiente. Os resultados experimentais confirmaram a existência de amoníaco na forma iónica no estado sólido. Contudo, estes só são parcialmente concordantes com as estruturas cristalinas sugeridas no modelo estrutural previsto pelos estudos teóricos anteriores. Cálculos teóricos adicionais ajudaram a equipa a refinar o modelo e sugerem que a fase iónica a pressão elevada contém, de facto, duas formas cristalinas distintas. A forma cris-

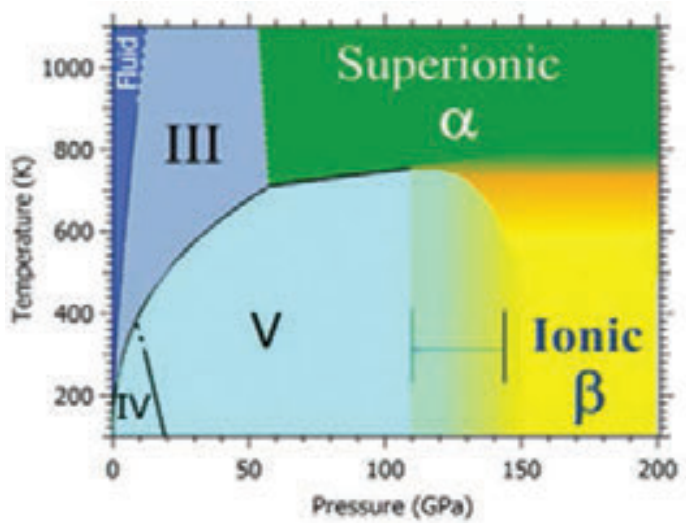

(adaptado de http://www.rsc.org/chemistryworld/2014/01/ammonia-freezes-under-pressure e de S. Ninet et al., arXiv:1401.1419v1)

Paulo Mendes (pjgm@uevora.pt) 